\title{
Review
}

\section{Advances in induced resistance by natural compounds: towards new options for woody crop protection}

\author{
Eugenio Llorens * Pilar García-Agustín, Leonor Lapeña
}

University Jaume I - Dept. of Agricultural and Environmental Sciences, Av. Sos Baynat, s/n - 12071 - Castellón de la

Plana - Spain.

*Corresponding author <ellorens@uji.es>

Edited by: Paulo Cesar Sentelhas

Received January 13, 2016

Accepted March 29, 2016
ABSTRACT: The activation of defensive responses of plants is a promising tool for controlling pests in conventional agriculture. Over the last few years, several compounds have been studied to protect crops from pests, without displaying direct toxicity for pathogenic organisms. These compounds have the ability to induce a priming state on the plants that results in resistance (or tolerance) against subsequent infection by a pathogen. In terms of molecular response, induced plant defense involves a broad number of physical and biochemical changes such as callose deposition or phenolic compounds, activation of salicylic and/or jasmonic acid pathways or synthesis of defense-related enzymes. Despite the large number of studies performed to ascertain the physiological and biochemical basis of induced resistance, only a few resistance-activating compounds have been studied as a real alternative to classic means of control and the studies geared towards incorporating induced resistance into disease management programs are relatively rare. The incorporation of natural resistance inducer in pest management programs of woody crops, alone or in combination with classical methods, could be a reliable method for reducing the amount of chemical residues in the environment. In this review, we discuss the current knowledge of induced resistance in woody crops, focusing on the mode of action of compounds authorized for conventional agriculture. We conclude by discussing the environmental and economic advantages of applying resistance inducers to conventional agriculture with special emphasis on natural compounds.

Keywords: priming, enhanced resistance, pest management, induced systemic resistance, systemic acquired resistance

\section{Introduction}

Different stresses, both biotic and abiotic, to which plants are subjected, can lead to alterations in their physiological state which, in the case of species with agronomic interest, can result in important reductions in yield and crop quality (Atkinson et al., 2011; Hodges and Toivonen, 2008). Due to their immobility, plants have developed systems to counteract these situations by activating specific defensive pathways intended for various types of threats. For this reason, primary resistance mechanisms such as preformed defenses have evolved to face the biotic and abiotic stress that can appear in the environment. The first barrier is non-specific passive protection against any kind of attack, provided by the waxy cuticle and the accumulation of antimicrobial compounds such as saponins or piretrines (Osbourn, 1996) and other secondary metabolites such as phytoalexins and phytoanticipins. However, plants have also evolved sophisticated defense mechanisms to perceive pathogen attacks and to translate that perception into an adaptive response (Hammerschmidt, 2009; Hammerschmidt, 2012).

Plants are able to respond to the presence of pathogens either by recognition of PAMPs (pathogens (microbe)-associated molecular patterns) or pathogen effectors, which lead to the activation of PAMP-triggered immunity (PTI), or effector-triggered immunity (ETI) (Jones and Dangl, 2006). Currently, there is the perception of PAMPs and effectors acting as "layers" of defense specifically activated according to the level of "danger" by a certain non-pathogen, weak pathogen or sophisticated pathogen. Plants have the ability to perceive certain attacks and initiate responses accordingly (Pritchard and Birch, 2014). When a pathogen is recognized, the speed and accuracy with which the plant cell can mobilize its defenses often determine if the plant will resist the attack (Hammond-Kosack and Parker, 2003; Pastor et al., 2014).

\section{Basis of induced resistance in plants}

Induced resistance triggered by pathogens could be divided depending on the type of pathogen into: systemic acquired resistance (SAR), herbivore induced resistance (HIR) and induced systemic resistance (ISR) (Pieterse et al., 2014). SAR is a form of induced resistance in plants with a specific defense signaling pathway that occurs systemically after localized exposure to a pathogen or alternatively, after treatment with synthetic or natural compounds (Hammerschmidt, 2009). It is also defined as the resistance dependent on the accumulation of salicylic acid (SA) and activation of Nonexpressor of Pathogenesis-related protein 1 (NPR1). SA is accumulated after pathogen infection, binding NPR1 to 
activate induction of Pathogenesis-related genes $(P R)$. NPR1 is present in cytoplasm as an oligomer (inactive form) which avoids SAR activation in the absence of a pathogen. The binding with SA induces changes in the dimer form of NPR1, and releases the C-terminal transactivational domain which enables NPR1 to activate the expression of defense genes. However, in the first stages of inoculation, very high levels of SA promote the interaction of NPR1 with its paralog NPR3, leading to NPR3-mediated degradation of NPR1 and provoking hypersensitive responses (HR) (Gozzo and Faoro, 2013). SAmediated resistance is effective against a broad range of pathogens, such as bacteria, fungi or viruses. However, it is known that SAR is usually most effective against biotrophic and hemibiotrophic pathogens (Glazebrook, 2005; Hammerschmidt, 2009).

Despite SA accumulation in the phloem, experiments on tobacco demonstrated that SA is not the systemic SAR signal (Vernooij et al., 1994). However, recent studies have pointed to several metabolites that may be involved in long-distance SAR signaling, such as the methyl ester of SA (MeSA), dehydroabietinal (DA), azelaic acid (AzA), and pipecolic acid (Pip) (Dempsey and Klessig, 2012; Shah and Zeier, 2013).

On the contrary, ISR was primarily described as a response induced by plant growth-promoting rhizobacteria (PGPR) (Pieterse et al., 2000), but can also be induced by other compounds such as antibiotics, surfactants or chemical inducers (Gozzo and Faoro, 2013). ISR, in contrast to SAR, does not involve the accumulation of SA, but is dependent on jasmonic acid (JA) and ethylene (ET) signaling pathways and also requires NPR1 (Pieterse and Van Loon, 2004; Pieterse and Van Loon, 2007). However, the activation of ISR is not associated with the expression of PR genes (Van Loon et al., 1998). The two major branches of the JA signaling pathway are controlled by the transcription factor $M Y C 2$ and the ethylene response factor (ERF). The ERF branch of the JA pathway is associated with enhanced resistance to necrotrophic pathogens and is regulated by members of the apetala2/ ethylene response factor $(A P 2 / E R F)$ family, including the JA-responsive marker gene plant defensin1.2 (PDF1.2) (Berrocal-Lobo et al., 2002; Lorenzo et al., 2003). On the other hand, the JA also mediates resistance against herbivores (HIR). After leaf wounding, an increment of the JA derivative Jasmonoyl-isoleucine (JA-Ile) is perceived by a complex consisting of the protein Coronatine insensitive1 (COI1) and Jasmonate ZIM-domain (JAZ) protein. When the hormone is perceived, JAZ repressors are degraded by the proteasome releasing MYC2 and allowing the activation of JA responses such as the accumulation of vegetative storage protein2 (VSP2) (Chini et al., 2009; Pieterse et al., 2014). However it has also been demonstrated that MYC2 plays a role in induced resistance against pathogens (Pozo et al., 2008; Pré et al., 2008). On the other hand, herbivores also trigger the production of volatiles that attract natural predators and induce defenses either in distal parts of the same plant or in neighboring plants (Dicke and Baldwin, 2010; Erb et al., 2015; Heil and Ton, 2008). It has been demonstrated that volatiles derived from linoleic pathway increase sensitivity to methyl jasmonate and induce several defenserelated genes, such as chalcone synthase $(C H S)$, allene oxide synthase $(A O S)$, hydroperoxide lyase $(H P L)$ and lipoxygenase2 (LOX2) (Bate and Rothstein, 1998; Gomi et al., 2003; Hirao et al., 2012).

\section{Effectiveness of induced resistance in conventional woody crops}

It is widely known that the exposure of plants to certain stresses can induce a state of sensitization in the whole plant; characterized by faster and stronger activation of cellular defenses upon invasion. This state is known as a priming of defense (Conrath, 2009; Goellner and Conrath, 2008; Jung et al., 2009; Pastor et al., 2013).

Priming inducers can be divided into synthetic or natural compounds. Synthetic compounds are those that cannot be found or rarely occur in nature, such as Acibenzolar-S-methyl (ASM, syn. benzothiadiazol BTH) and 2.6-dichloroisonicotinic acid (INA). On the other hand, the group of natural inducers includes substances which are synthetized by the plant in response to stress signals such as SA, JA or azelaic acid (Jung et al., 2009) and other natural compounds that are not derived or related to plant defensive pathways, such as hexanoic acid ( $\mathrm{Hx}$ ) (AranegaBou et al., 2014). These compounds have the advantage of being easily found in nature such as chitin from crustaceous exoskeletons (Xing et al., 2015) or laminarin from algae (Aziz et al., 2003). Application of these resistance inducers, either synthetic or natural, can protect the plants against a broad spectrum of diseases caused either by fungi or bacteria, such as brown spot caused by Alternaria alternata Keissl or citrus canker caused by Xanthomonas citri (Hasse) (Conrath, 2009; Jakab et al., 2001; Llorens et al., 2013; Llorens et al., 2015), including a number of crop diseases that are difficult to control through conventional management disease strategies (Li et al., 2015). However, despite the positive results these compounds have shown in model plants and herbaceous crops, only a few of them have been tested in woody plants.

\section{Synthetic resistance inducers}

Synthetic resistance inducers are small molecules that activate defense reactions by mimicking interactions of natural elicitors or defense signaling molecules. These compounds are structurally different from natural plant defense inducers. The effectiveness of synthetic resistance inducers was first reported in the 1970 s by the description of certain compounds that activate the PR1 gene expression (Kassanis and White, 1975). A few years later, Probenazole (PBZ), was described as an effective inducer of defense-related enzymes becoming the first resistance inducer with a trademark. Since that time, several studies have described the effectiveness and potential use of synthetic elicitors in woody crops (Table 1). 
Llorens et al. Induced resistance in woody crops

Table 1 - Chemical resistance inducers described in this work.

\begin{tabular}{|c|c|c|c|c|}
\hline Compound & Plant tested & Stress tested & Response induced & Reference \\
\hline \multirow[t]{3}{*}{ Acibenzolar-S-methyl } & Apple & Erwinia amylovora & $\begin{array}{l}\text { Pathogenesis related (PR) genes PR-1, PR-2, and } \\
\text { PR-8 gene expression }\end{array}$ & $\begin{array}{l}\text { Aćimović et al., } 2015 \\
\text { Maxson-Stein et al., } 2002\end{array}$ \\
\hline & Japanese pear & Venturia nashicola & $\begin{array}{l}\text { Peroxidase, Superoxide dismutase, Catalase, } \\
\text { Ascorbate peroxidase and Biosynthesis of terpenoids }\end{array}$ & Faize et al., 2004 \\
\hline & Citrus & Xanthomonas citri & PR-2 gene expression & $\begin{array}{l}\text { Graham and Myers, } 2011 \\
\text { Llorens et al., } 2015\end{array}$ \\
\hline Imidaclorprid & Citrus & Xanthomonas citri & PR-2 gene expression & Francis et al., 2009 \\
\hline \multirow[t]{4}{*}{$\beta$-aminobutyric acid } & Olive & Spilocaea oleagina & Not studied & Obanor et al., 2013 \\
\hline & Grapevine & Plasmopara viticola & PR proteins & $\begin{array}{l}\text { Harm et al., } 2011 \\
\text { Reuveni et al., } 2001\end{array}$ \\
\hline & Citrus & $\begin{array}{c}\text { HLB } \\
\text { Xanthomonas citri } \\
\text { Diaphorina citri }\end{array}$ & PR proteins & $\begin{array}{l}\text { Li et al., } 2015 \\
\text { Tiwari et al., } 2013 \\
\text { Behesthti et al., } 2011\end{array}$ \\
\hline & Crabapple & Drought & Abscisic acid and cell wall strength & Macarisin et al., 2009 \\
\hline
\end{tabular}

Salicylic analogues: Acibenzolar-S-methyl, Isonicotinic acid and Imidaclorpid

ASM is one of the most studied compounds. In a review published by Vallad and Goodman in 2004, the authors describe the effects of ASM and INA on 12 different crops against more than 30 pests, reporting effectiveness of between 60 and $80 \%$. This functional analogue of salicylic acid acts downstream from SA accumulation through the activation of SA-response mechanisms. Thus, application of this compound induces similar responses in plants to those induced by biotrophic pathogens or SA, including the characteristic overexpression of $P R$ genes (Friedrich et al., 1996). Recent studies suggest that acibenzolar is the active molecule in ASM. Tobacco plants (Nicotiana tabacum L.), with the gene SABP2 (SA-binding protein 2) silenced, are not able to metabolize the ASM in acibenzolar and, consequently, are not able to induce SAR by ASM treatment. On the other hand, the treatment with acibenzolar, showed full induction of SAR in the same silenced plants (Tripathi et al., 2010). In addition, intense use of foliar-applied ASM resulted in a significant reduction in growth and yield when applied weekly to pepper crops (Romero et al., 2001). This reduction has been attributed to the physiological cost of constitutive induction of plant defense (Van Loon et al., 2006; Walters and Fountaine, 2009).

Over the last few years, several studies have shown the ability of ASM to induce resistance to fire blight (Erwinia amylovora Winslow) in apple by reducing the rate of inoculation by $70 \%$ when the compound is applied as foliar spray 4 days before inoculation (Baysal and Zeller, 2004). Whereas in the field trunk injection of ASM resulted in a reduction of this pathogen by nearly $40 \%$. The protection achieved in 'Golden delicious' or mature 'Gala' apple trees against $E$. amilovora was usually correlated with the up regulation of PR-genes such as $P R-1, P R-2$ and $P R-8$ and terpenoid biosynthetic enzymes (Aćimović et al., 2015; Maxson-Stein et al., 2002). However, no significant enhancement in $P R-1 a, P R-2$, and $P R-8$ genes was detected in 1 year-old 'Gala' apple trees treated with ASM (Bonasera et al., 2006).

In Japanese pear (Pyrus pyrifolia Naka var. Culta), the application of ASM reduces the incidence of pear scab caused by Venturia nashicola Tanaka et Yamamoto by $40 \%$ compared to control plants. This reduction was correlated with a higher activation rate of principal antioxidant enzymes such as peroxidase (POX), superoxide dismutase (SOD), catalase (CAT), ascorbate peroxidase (APX) and an enhancement of polygalacturonase-inhibiting proteins (PGIP) which are involved in the inactivation of fungal polygalacturonases (Faize et al., 2004).

Applications of ASM, either as foliar spray or soil drench, was able to reduce by $50 \%$ the lesions produced in citrus by Xanthomonas citri and $X$. axonopodis pv. Citrumelo (Hasse) (Graham and Myers, 2011). Similar to those in apple, greenhouse treatments with ASM in 'Pineapple' sweet orange (Citrus sinensis Osbeck) plants induced a $P R-2$ response that lasted up to 21 days after foliar application (Llorens et al., 2015). On the contrary, soil applications of ASM achieved almost total protection with $80 \%$ lesion reduction for several weeks after soil application which was directly correlated with a persistent expression of the PR-2 gene form (Francis et al., 2009).

Similar results showing protective effects have been obtained with applications of the insecticide Imidacloprid (IMID). This insecticide breaks down in planta into 6-chloronicotinic acid, analogous to INA, which induces a SAR response (Ford et al., 2010). Francis et al. (2009), in a greenhouse pot trial with 'Swingle' Citrumelo plants (Citrus paradisi Macfad $\times$ Poncirus trifoliata Raf), confirmed that soil drenches of IMID, as well as ASM, induced a high and persistent up-regulation of $P R$ - 2 gene expression that was correlated with a reduction of more than $75 \%$ canker lesions for up to 27 weeks. In greenhouse experiments, a single soil drench application of IMID is able to protect the plants against $X$. citri with the same effectiveness as weekly applications of copper as a foliar spray (Francis et al., 2009). 


\section{Non-protein amioacids: $\beta$-aminobutyric acid}

$\beta$-aminobutyric acid (BABA) is a non-protein amino acid, isomer of the highly bioactive neurotransmitter $\gamma$-aminobutyric acid (GABA). However, BABA occurs rarely in nature. This compound is known to induce resistance in plants against biotic and abiotic stresses by inducing both SA-dependent and SA-independent defense mechanisms (Ton et al., 2005; Zimmerli et al., 2000). In greenhouse experiments, this compound was able to reduce by $60 \%$ the incidence of Olive leaf spot (Spilocaea oleagina (Hughes)) in 2 year old plants (Obanor et al., 2013). In field trials, BABA was also shown to be effective in grapevines (Vitis vinifera L.) reducing the severity of leaf lesions of downy mildew caused by Plasmopara viticola de Toni by $57 \%$ on cv. Chardonnay and by $98 \%$ on cv. Cabernet Sauvignon (Harm et al., 2011; Reuveni et al., 2001) which were related to an enhancement of PR proteins. Application of BABA on citrus against Hunaglongbing disease (HLB) caused by 'Candidatus Liberibacter asiaticus' showed and enhanced expression of the $P R$-2 gene that seems to involve an SA-dependent pathway. However, induction of Callose synthase 1 (CalS1) gene by BABA was not observed, excluding the implication of callose deposition (Li et al., 2015). Moreover, all three developmental stages of HLB vector Diaphorina citri Kuwayama were negatively impacted by BABA through induction of host-plant resistance in citrus. Tiwari et al. (2013) demonstrated that the $P R-2$ gene was up-regulated by more than 150-fold in citrus treated with BABA in combination with $D$. citri adult feeding compared with the control or citrus treated with BABA or D. citri feeding alone. These results provide an alternative tool for current D. citri management programs that are based exclusively on insecticides. Other studies have also shown the efficacy of BABA against Xanthomonas citri in key lime but the implication of PR proteins is unclear (Beheshti et al. 2011). In crabapple (Malus pumila Mill), BABA induced drought stress resistance by potentiating abscisic acid (ABA) pathway and several ABA-independent responses, such as changes in cell wall enzymes and a suppression of lignin (Macarisin et al., 2009).

\section{Natural resistance inducers}

\section{Natural compounds: Hexanoic acid}

Several plant extracts were shown to be effective as priming inducers (Table 2). Hexanoic acid is a natural compound produced by strawberry (Fragaria vesca L.) and arbutus (Arbutus unedo L.) (Soufleros et al., 2005; Zabetakis et al., 2000). This natural short-chain monocarboxylic acid is able to induce plant defense responses when used as a priming agent (Aranega-Bou et al., 2014). Post-infection, oxylipin (1,2-oxo-phytodienoic acid; OPDA) and the bioactive molecule jasmonate-isoleucine (JA-Ile) showed significant enhancement. One differential characteristic of hexanoic acid is that, after soil application, this compound is absorbed and accumulated by the roots but it is not translocated to other parts of the plants (Vicedo et al., 2009). Novel studies demonstrated that the application of this compound in tomato (Solanum lycopersiccum L), induces changes in the plant that can alter the expression of virulence in genes of Pseudomonas syringae Van Hall re-

Table 2 - Natural resistance inducers described in this work.

\begin{tabular}{|c|c|c|c|c|}
\hline Compound & Plant tested & Stress tested & Response induced & Reference \\
\hline Hexanoic acid & Citrus & $\begin{array}{l}\text { Alternaria alternata } \\
\text { Xanthomonas citri }\end{array}$ & $\begin{array}{l}\text { Jasmonic acid, Pathogenesis related (PR) genes } \\
\text { PR-2, Callose deposition, Phenolic compounds }\end{array}$ & $\begin{array}{l}\text { Vicedo et al., } 2009 \\
\text { Llorens et al., 2013; } 2015 \\
\text { Scalschi et al., 2014 }\end{array}$ \\
\hline Laminarin & Grapevine & $\begin{array}{c}\text { Botrytis cinerea } \\
\text { Plasmopara viticola }\end{array}$ & $\begin{array}{l}\text { Phenylalanine ammonialyase (PAL), Lipoxygenase } \\
\text { (LOX), Glucanase (GLU) and Chitinase (CHI) activity }\end{array}$ & Trouvelot et al., 2008 \\
\hline Ulvan & Apple & $\begin{array}{l}\text { Penicillium expansum } \\
\text { Botrytis cinerea }\end{array}$ & $\begin{array}{l}\text { Catalase (CAT), Superoxide dismutase (SOD), PAL, } \\
\text { Peroxidase (POX) and Polyphenoloxydase (PPO) } \\
\text { enhanced levels of lignin and phenolic compounds }\end{array}$ & Abouraïcha et al., 2015 \\
\hline \multirow[t]{3}{*}{ Chitosan } & Peach & Monilinia fructicola & CAT, POX, $\beta$-1.3-glucanase, CHI & Ma et al., 2013 \\
\hline & Pinus & Fusarium circinatum & PAL & $\begin{array}{l}\text { Reglinski et al., } 2004 \\
\text { Fitza et al., } 2013\end{array}$ \\
\hline & Grapevine & Plasmopara viticola & PAL, Chalcone synthase, PR proteins & Xing et al., 2015 \\
\hline \multirow[t]{2}{*}{$\begin{array}{l}\text { Menadione sodium } \\
\text { bisulphite }\end{array}$} & Banana & Fusarium oxysporum & Ascorbate peroxidase, Phytoalexines & Borges et al., 2003a \\
\hline & Citrus & $\begin{array}{l}\text { Trioza erytreae and } \\
\text { Diaphorina citri }\end{array}$ & Not studied & Borges et al., 2014 \\
\hline \multirow[t]{2}{*}{ Thiamine } & Grapevine & Plasmopara viticola & $\mathrm{H}_{2} \mathrm{O}_{2}$ burst, callose deposition and phenolic compounds & Boubakri et al., 2013a; 2013b \\
\hline & Pear & Alternaria alternata & $\begin{array}{l}\text { PAL, PPO, POX, increased levels of flavonoids and } \\
\text { phenolic compounds }\end{array}$ & Yin et al., 2012 \\
\hline Riboflavin & Grapevine & Plasmopara viticola & $\mathrm{H}_{2} \mathrm{O}_{2}$ burst, $\mathrm{PR}$ genes and LOX & Boubakri et al., 2013b \\
\hline Arbuscular mycorrhiza & Citrus & Phytophtora sp. & Not studied & $\begin{array}{l}\text { Watanarojanaporn et al., } 2011 \\
\text { Graham et al., } 2012\end{array}$ \\
\hline Ammonium & Citrus & salinity & CAT, SOD, and Glutatione reductase & Fernández-Crespo et al., 2012 \\
\hline
\end{tabular}


sponsible for bacterial speck disease, showing for the first time that the application of resistance inducers not only enhances plant defenses but also reduce the virulence of the pathogen itself (Scalschi et al., 2014).

In citrus, this compound is able to reduce the incidence of Alternaria alternata by $50 \%$ in 'Fortune' mandarin (Citrus clementina Tanaka $\times$ Citrus reticulata 'Dancy' Blanco) when it is applied as a soil drench. Treated and infected plants showed higher levels of callose deposition as well as expression of PGIP genes and an enhancement of the jasmonic acid pathway (Llorens et al., 2013). In long lasting tests, treated plants showed enhanced levels of phenolic compounds, such as caffeic and chlorogenic acids. Moreover, $\mathrm{Hx}$ application to sweet orange plants (Citrus sinensis Osbeck) reduced the incidence of Xanthomonas citri subsp. citri by $50 \%$ and activated the expression of the PR-2 gene (Llorens et al., 2015).

\section{Algi extracts: ulvan and laminarin}

Recently, it has been shown that polysaccharides, mainly ulvans, laminarin and carrageenans, from green, brown and red algae can trigger defense responses in plants enhancing protection against pathogens. Laminarin is a linear $\beta-1,3$ glucan extracted from the brown alga Laminaria digitata Lamouroux. In vitro tests demonstrated that treatment with laminarin induced an increase in phenylalanine ammonia-lyase (PAL) and LOX transcripts in grapevine cells, and a sustained increase in glucanase and chitinase (Aziz et al., 2003). Applications of laminarin to grapevine plants reduced infection by Botrytis cinerea Pers (grey mold disease) and $P$. viticola in leaves by approximately 55 and $85 \%$. However, the application of inhibitors of LOX gene and callose synthesis reduced the effectiveness of laminarin up to $80 \%$, suggesting that its effect principally relies on the JA pathway (Trouvelot et al., 2008).

Ulvan is a water-soluble sulfated polysaccharide extracted from several green algae, representing 8 to $29 \%$ of the algal dry weight. Recent studies have shown that ulvan could induce resistance in several plants such as apple against blue mold by Penicillium expansum Link (blue mold) and Botrytis cinerea inducing the activation of CAT and SOD, PAL, POX and polyphenoloxydase (PPO) as well as the levels of lignin and phenolic compounds (Abouraïcha et al., 2015). These studies and others with chemical sulfation of laminarin, suggested that the enhancement of defense responses by algae extracts can be related to its sulfate residue (El Modafar et al., 2012; Gauthier et al., 2014).

\section{Polysaccharides: Chitosan}

Chitosan is a nontoxic, biodegradable biopolymer derived from chitin present in the exoskeletons of crustaceans and insects, as well as in certain fungal cell walls (Xing et al., 2015). This natural compound is marketed alone or in combination with other compounds and sold as a plant growth regulator and inducer of disease resistance in different crops. Although its protective effect mainly derives from the stimulation of natural defenses of plants, it also exhibits antimicrobial activities against fungi and bacteria (Chirkov, 2002). Applied as an exogenous elicitor, chitosan has shown efficacy against downy mildew in grapevines (Plasmopara viticola) in field trials (Xing et al., 2015) and against pitch canker caused by Fusarium circinatum Nirenberg et O'Donnell in Pinus radiata D. Don (Reglinski et al., 2004). The activation of defense mechanisms can vary depending on the species. It has been demonstrated that, in vitro, grapevine cells treated with chitosan showed up regulation of phenylalanine ammonia lyase (PAL), chalcone synthase and enhanced expression of eleven proteins of the pathogenesis related protein family (Ferri et al., 2009). In the same way, chitosan treatments in peach (Prunus persica L) against brown rot caused by Monilinia fructicola Honey enhanced antioxidant and defense-related enzymes, such as CAT, POX, $\beta$-1,3-glucanase (GLU) and chitinase (CHI) (Ma et al., 2013). However, in Pinus patula Schltdl. \& Cham. against Fusarium circinatum, only the up regulation of PAL was observed, whereas no differences in the expression of PR genes were found (Fitza et al., 2013) suggesting that the activation of hormonal pathways is also dependent on the species and stress.

\section{Vitamins: thiamine, riboflavin and Menadione so- dium bisulphite}

Vitamins are essential components of the plant physiology that can take part in different processes such as photosynthesis, energy generation and redox metabolism (Sandoval et al., 2008) or act as enzymatic cofactors in universal metabolic pathways such as glycolysis or Krebs cycle (Goyer, 2010). However, in the last few years it has also been demonstrated that the application of certain vitamins such as thiamine (vitamin B1), riboflavin (vitamin B2) or Menadione sodium bisulphite (MSB or provitamin $\mathrm{K}$ ) are able to induce resistance in a wide range of plants. MSB is a water soluble addition compound of vitamin K3 previously described as a plant growth regulator with strong redox properties. The application of this vitamin has demonstrated effectiveness as a resistance inducer in banana plants (Musa acuminata) against Panama disease of banana caused by Fusarium oxysporum related to an increment of phytoalexins (Borges et al., 2003a). In oilseed rape (Brassica napus) MSB is able to induce an enhancement of APX but no effect on PR-1 expression was observed, suggesting that resistance mediated by MSB in oilseed rape involves an enhanced production of reactive oxygen species (ROS) but is independent of PR-1 accumulation (Borges et al., 2003b). Moreover it has been suggested that the application of MSB is able to induce a reduction in insect growth rate which could be used for controlling Trioza erytreae and Diaphorina citri, the psyllid vectors of HLB (Borges et al., 2014).

The first report of thiamine as an inductor of defenses in plants was in 1985 when Asselin et al. observed that exogenous applications were able to induce the accumulation of PR proteins. Some years later, Malamy et 
al. (1996) demonstrated that the application of thiamine induces the expression of the $P R-1$ gene resulting in an enhancement of resistance against Tobacco mosaic virus. However, this effect was not observed in mutants encoding the salicylate hydroxylase $\mathrm{NahG}$, which are unable to accumulate salicylic acid, suggesting that thiamine is able to induce responses in an Sa-dependent manner. Subsequent investigations demonstrated that thiamine application is able to induce several defensive responses such as PAL, callose deposition as well as suggest that hydrogen peroxide can play a major role in thiamine induced resistance (Ahn et al., 2007). In grapevine, thiamine is able to induce resistance against Plasmopara viticola by inducing the generation of hydrogen peroxide, enhancement of callose deposition in stomata cells and phenolic compound accumulation (Boubakri et al., 2013a). In Asian pear (Pyrus bretschneideri Rehd. cv. $\mathrm{Zaosu}$ ) thiamine is able to induce resistance against $\mathrm{Al}$ ternaria rot caused by Alternaria alternata by the enhacement of PAL, PPO and POX, and increases in the content of flavonoids and phenolic compounds (Yin et al., 2012).

Riboflavin is a vitamin produced by and is present in plants acting as a coenzyme in many physiological processes that can affect the production of reactive oxygen intermediates and oxidative burst. Exogenous applications of riboflavin enhances the resistance of Arabidopsis thaliana against Peronospora parasitica (Downy Mildew) and Pseudomonas syringae, tobacco against Tobacco mosaic virus and Alternaria alternata. Unlike thiamine, riboflavin is able to induce resistance and $P R$ gene expression in NahG plants which indicates that its protective effect is independent of SA. Moreover, mutations in the NIM1/ NPR1 (non inducible immunity/non-expressors of PR) gene which controls transcription of defense genes, reduced the effect of the treatment, suggesting that riboflavin requires protein kinase signaling mechanisms and a functional NIM1/NPR1 gene (Dong and Beer, 2000). On the other hand, it has been observed that the application of riboflavin also correlates with JA pathway activation by enhancement of the LOX gene and the up-regulation of the PAL (Aranega-Bou et al., 2014). In grapevine against $P$. viticola, applications of riboflavin induced defense responses including $\mathrm{H}_{2} \mathrm{O}_{2}$ generation, enhanced expression of several $P R$ genes, callose deposition and the enhancement of LOX expression which indicates an involvement of jasmonic acid (Boubakri et al., 2013b).

\section{Induced resistance from the soil: Arbuscular my- corryza and Ammonium nutrition}

Nevertheless, enhancement of resistance in plants is not restricted to soil or foliar applications of inducers. Arbuscular mycorrhiza (AM) can usually confer better plant growth, higher nutrient uptake, higher tolerance to abiotic and biotic stresses in the host plant and improve the soil structure. Several studies demonstrated that AM-inoculated rough lemon (Citrus jambhiri Lush) plants showed higher tolerance to drought stress or saltaffected soils (Wu et al., 2013). Abiotic stress strongly restricted both the development of non-AM-citrus and the mycorrhizal development of AM-citrus, but AM colonization produced a positive effect on plant growth and photosynthesis, even under drought or salinity stresses.

Colonization with AM is reported to induce stronger and faster defense responses in the host plant against root as well as shoot pathogens. Tomato plants colonized with AM showed induced systemic resistance, against the $A$. alternata, reducing the number of lesions per leaf. This reduction was related to an increase in methyl jasmonate (MeJA) levels in the leaves as well as the genes LOX and OPR3 (12-oxophytodienoate reductase 3) involved in JA biosynthesis (Nair et al., 2015). In bean (Phaseolus vulgaris L.), AM colonization led to a significant increase in the phenolic content and the activities of PAL and PPO (Al-Askar and Rashad, 2010). Studies performed by Watanarojanaporn et al. (2011) demonstrated that the use of certain AM improves both growth of citrus and tolerance to root rot disease caused by Phytophthora spp. in C-35 citrange $(C$. sinensis $\times P$. trifoliate), Shogun (Citrus reticulata Blanco cv. Shogun) and Tangerine (C. reticulata). However, in recent studies Graham et al. (2012) concluded that protection of citrus roots induced by hypovirulent $P$. nicotianae Haan against infection by Phytophthora spp. is not related to induction of systemic acquired resistance.

Novel studies about citrus nutrition, demonstrated that ammonium-based fertilization could also induce resistance in trees. Fernández-Crespo et al. (2012) observed that $\mathrm{NH}_{4}{ }^{+}$treatments induced a mild stress condition that primes the Carrizo citrange $\mid C$. sinensis $\times$ Poncirus trifoliata) defense response by stress imprinting and confers protection against subsequent salt stress. Moreover, plants grown with $\mathrm{NH}^{+}$showed lower levels of $\mathrm{H}_{2} \mathrm{O}_{2}$ when exposed to salinity. At the same time activation of the plant antioxidant machinery by an increase in CAT, SOD, and glutathione reductase (GR) activities was observed compared to the control plants (Fernández-Crespo et al., 2014).

\section{Costs and benefits of induced resistance}

In recent years, the possible costs associated with enhanced induction of defenses have been pointed out as being one of the major drawbacks of the commercial use of resistance inducers (Van Hulten et al., 2006; Walters and Heil, 2007). The main theory suggests that the energy and resources that are diverted to the synthesis of defensive compounds, cannot be used in the primary metabolism, provoking growth reduction and other fitness costs. Unfortunately, this theory is supported by the negative effects of a number of resistance inducers when applied in high doses or repeatedly. It is known that chitosan, can reduce Vitis plantlet growth and shoot length when used in concentrations higher than $2 \%$ (Barka et al., 2004). In sunflower, high concentrations of ASM (2 $\mathrm{mg} \mathrm{mL}^{-1}$ ) resulted in light chlorosis and reductions in fresh weight (Prats et al., 2002) and reduced the yield in pepper when applied weekly during the entire crop 
season (Romero et al., 2001). Similar deleterious effects were observed with BABA or INA (Oostendorp et al., 2001; Wu et al., 2010). On the other hand it has been widely reported that the correct dosage could be beneficial in terms of plant protection (Aranega-Bou et al., 2014; Borges and Sandalio, 2015; Walters et al., 2013). For example, the use of ASM in tomato against bacterial spot (Xanthomonas axonopodis Hasse pv. vesicatoria) and bacterial speck (Pseudomonas syringae pv. tomato) showed disease control was similar or superior to that obtained when using copper and yield was not affected (Louws et al., 2001).

Classical crop protection is usually carried out by the application of several preventive treatments during the season and sometimes, after the attack of pathogens, curative treatments, which often suppose the presence of residues of one or more pesticides in the fruits and veg- etables (Figure 1A). The main benefit these compounds could offer to conventional crop management practices is a reduction in the number of sprays of conventional pesticides. All the resistance inducers have a preventive action, enhancing the natural defenses of the plants and reducing the preventive pesticide application treatments or frequency (Figure 1B). Usually the induced resistance is strong enough to protect plants against low-mid pressure stresses. However, in cases of high disease pressure that overcome the natural defenses of the plant, the combination of resistance inducers with classical treatments can achieve complete protection (Figure 1C). For example, BABA root treatments are able to improve the effect of Mancozeb foliar treatments against downy mildew (Baider and Cohen, 2003) which demonstrate that the application of a resistance inducer can reduce the amount of fungicides on induced plants.
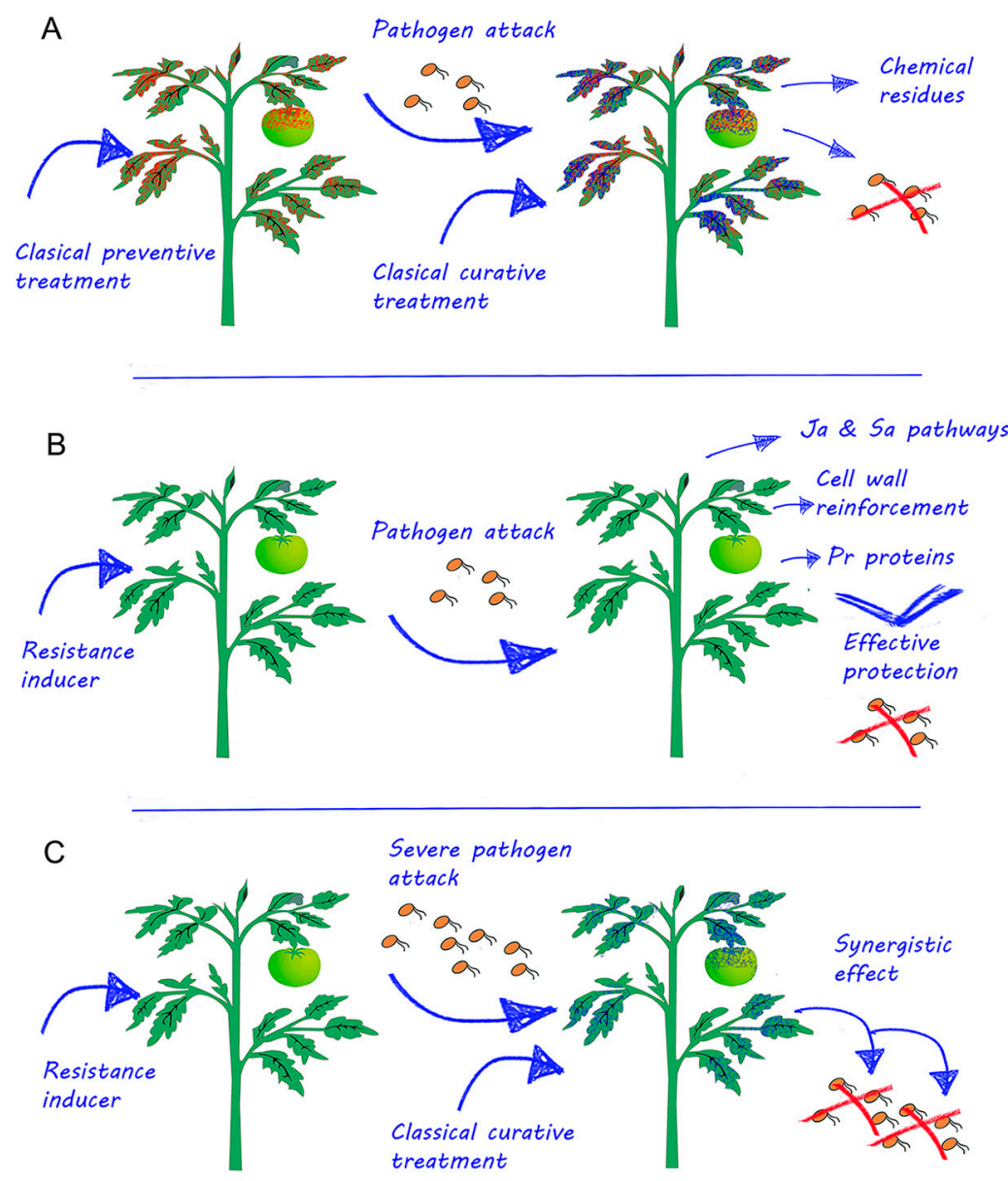

Figure 1 - Different pest management methods in current agriculture. A) Classical control usually composed by chemical preventive treatment and, after incidence of pathogen, a curative treatment. This method usually can control the pest, but can deposit large amount of residues on fruit. B) Resistance inductor treatment applied as a preventive treatment confers resistance to the plants and, after incidence of pathogen, plants can activate several mechanisms of defense that are usually sufficient to control the pest (SA: salicylic acid; JA: Jasmonic acid; PR proteins: pathogenesis related proteins). C) In the case of severe pest incidence both methods can be combined, namely, a previous treatment with a resistance inducer complemented by a classic treatment. This method has the advantage of using chemical control only when is completely necessary, avoiding chemical preventive treatments thus reducing the amount of chemical residues. 
A synergistic effect of several resistance inducers, when applied in combination with classical pesticides, has been demonstrated. Field experiments with grapevines showed that BABA can enhance the activity of fosetyl-Al against Plasmopara viticola (Reuveni et al., 2001). Combinations of BABA with Mancozeb also demonstrated a synergistic effect against Phytophthora infestans de Bary and Pseudoperonospora cubensis Berkeley et Curtis in several crops (Baider and Cohen, 2003). ASM application reduced Erwinia amylovora in apple infection, but was less effective than classical treatments with streptomycin. However, the combination of both ASM and streptomycin, showed better protection than either treatment separately (Maxson-Stein et al., 2002). Furthermore, the combined application of ASM and $\mathrm{Cu}$ $(\mathrm{OH})_{2}$ resulted in disease control equal to that obtained with weekly applications of copper (Romero et al., 2001).

\section{Current and possible uses of resistance inducers in the field}

Despite all the investigations about induced resistance in plants, field applications are not a common practice, and only a few compounds have been tested or used in woody crops. It is well known that the protection obtained with inducers in the field against high pressure of disease is often incomplete. However, promising results were obtained when several resistance inducers were applied together or with chemical treatments. In citrus, application of BABA with ASM showed high and stable reduction of 'Candidatus Liberibacter asiaticus', reducing the population of bacteria near 1 Log unit per gram of tissue ( $\mathrm{Li}$ et al., 2015). The synergistic effect of resistance inducers (as a preventive compound or in combination with classical pesticides) can offer a valuable tool for reducing the residues of chemical pesticides in the fruits. However, these approaches need to be further studied in more detail in order to set up effective treatments. On the other hand, one of the most important problems of the abuse of chemical treatments is the appearance of resistant strains of pathogens. Copper-resistant strains of Xanthomonas citri have been identified in citrus groves in Argentina (Behlau et al., 2013). In a previous evaluation, ASM was particularly useful for management of bacterial speck and bacterial spot where copper-resistant strains predominated (Louws et al., 2001). Therefore, soil-applied SAR inducers could be employed for copper-resistance management by reducing the rate and frequency of copper bactericide applications.

The uses of natural endogenous compounds such as $\mathrm{Hx}$ acid or low toxicity compounds such as chitosan, are supposed to improve resistance against pests without chemical residues in the fruits or vegetables. A correct schedule of treatments with alternation between these compounds and classical ones could be useful for both reduction of pest damages and reduction of chemical residues. Moreover, the use of these priming agents in combination with nutritional compounds like $\mathrm{NH}_{4}{ }^{+}$or the colonization with arbuscular mycorrhiza could be an interesting alternative to preventive and curative treatments. By using these strategies, plants can achieve an enhanced basal resistance that permanently protects themselves against possible stresses.

\section{Acknowledgements}

This work was supported by grants from the "Research staff training program" of the University Jaime I, the Spanish Ministry of Science and Innovation (AGL2010-22300-C03-01-02 and AGL2013-49023-C0301-02-R) co-funded by the European Regional Development Fund (ERDF), Generalitat Valenciana Groups of Excellence (PROMETEO/2012-7066) and P1.1B2013-75 Plan for the Promotion of Research UJI.

\section{References}

Abouraïcha, E.; El Alaoui-Talibi, Z.; El Boutachfaiti, R.; Petit, E.; Courtois, B.; Courtois, J.; El Modafar, C. 2015. Induction of natural defense and protection against Penicillium expansum and Botrytis cinerea in apple fruit in response to bioelicitors isolated from green algae. Scientia Horticulturae 181: 121-128.

Aćimović, S.G.; Zeng, Q.; McGhee, G.C.; Sundin, G.W.; Wise, J.C. 2015. Control of fire blight (Erwinia amylovora) on apple trees with trunk-injected plant resistance inducers and antibiotics and assessment of induction of pathogenesis-related protein genes. Frontiers in Plant Science 6: 16.

Ahn, I.P.; Kim, S.; Lee, Y.H.; Suh, S.C. 2007. Vitamin B1-induced priming is dependent on hydrogen peroxide and the NPR1 gene in Arabidopsis. Plant Physiology 143: 838-848.

Al-Askar, A.A.; Rashad, Y.M. 2010. Arbuscular mycorrhizal fungi: a biocontrol agent against common bean Fusarium root rot disease. Plant Pathology Journal 9: 31-38.

Aranega-Bou, P.; Leyva, M.O.; Finiti, I.; García-Agustín, P.; González-Bosch, C. 2014. Priming of plant resistance by natural compounds: hexanoic acid as a model. Frontiers in Plant Science 5: 488.

Asselin, A.; Grenier, J.; Cote, F. 1985. Light-influenced extracellular accumulation of $\mathrm{b}$ (pathogenesis-related) proteins in Nicotiana green tissue, induced by various chemicals or prolonged floating on water. Canadian Journal of Botany 63: 1276-1283.

Atkinson, N.J.; Dew, T.P.; Orfila, C.; Urwin, P.E. 2011. Influence of combined biotic and abiotic stress on nutritional quality parameters in tomato (Solanum lycopersicum). Journal of Agricultural and Food Chemistry 59: 9673-9682.

Aziz, A.; Poinssot, B.; Daire, X.; Adrian, M.; Bézier, A.; Lambert, B.; Joubert, J.M.; Pugin, A. 2003. Laminarin elicits defense responses in grapevine and induces protection against Botrytis cinerea and Plasmopara viticola. Molecular Plant-Microbe Interactions 16: 1118-1128.

Baider, A.; Cohen, Y. 2003. Synergistic interaction between BABA and mancozeb in controlling Phytophthora infestans in potato and tomato and Pseudoperonospora cubensis in cucumber. Phytoparasitica 31: 399-409.

Barka, E.A.; Eullaffroy, P.; Clément, C.; Vernet, G. 2004. Chitosan improves development, and protects Vitis vinifera L. against Botrytis cinerea. Plant Cell Reports 22: 608-614. 
Bate, N.J.; Rothstein, S.J. 1998. C6-volatiles derived from the lipoxygenase pathway induce a subset of defense-related genes. The Plant Journal 16: 561-569.

Baysal, Ö.; Zeller, W. 2004. Extract of Hedera helix induces resistance on apple rootstock M26 similar to Acibenzolar-Smethyl against Fire Blight (Erwinia amylovora). Physiological and molecular Plant Pathology 65: 305-315.

Beheshti, B.; Sharifi-Sirchi, G.R.; Mansouri, M.; Hosseinipour, A.; Schlaich, N.L. 2011. Resistance to citrus canker in key/mexican lime induced by $\beta$-aminobutyric acid and green tea. American Journal of Agricultural and Biological Science 6: 242-248.

Behlau, F.; Hong, J.C.; Jones, J.B.; Graham, J.H. 2013. Evidence for acquisition of copper resistance genes from different sources in citrus-associated xanthomonads. Phytopathology 103: 409-418.

Berrocal-Lobo, M.; Molina, A.; Solano, R. 2002. Constitutive expression of Ethylene-Response-Factor1 in Arabidopsis confers resistance to several necrotrophic fungi. The Plant Journal 29: 23-32.

Bonasera, J.M.; Kim, J.F.; Beer, S.V. 2006. PR genes of apple: identification and expression in response to elicitors and inoculation with Erwinia amylovora. BMC Plant Biology 6: 23-23.

Borges, A.A.; Borges-Perez, A.; Fernandez-Falcon, M. 2003a. Effect of menadione sodium bisulfite, an inducer of plant defenses, on the dynamic of banana phytoalexin accumulation during pathogenesis. Journal of Agricultural and Food Chemistry 51: 5326-5328.

Borges, A.A.; Cools, H.J.; Lucas, J.A. 2003b. Menadione sodium bisulphite: a novel plant defence activator which enhances local and systemic resistance to infection by Leptosphaeria maculans in oilseed rape. Plant Pathology 52: 429-436.

Borges, A.A.; Jiménez-Arias, D.; Rodriguez, M.E.; Sandalio, L.M.; Pérez, J.A. 2014. Priming crops against biotic and abiotic stresses: MSB as a tool for studying mechanisms. Frontiers in Plant Science 5: 642.

Borges, A.A.; Sandalio, L.M. 2015. Induced resistance for plant defense. Frontiers in Plant Science 6: 109.

Boubakri, H.; Poutaraud, A.; Wahab, M.A.; Clayeux, C.; Baltenweck-Guyot, R.; Steyer, D.; Marcic, C.; Mliki, A.; SoustreGacougnolle, I. 2013a. Thiamine modulates metabolism of the phenylpropanoid pathway leading to enhanced resistance to Plasmopara viticola in grapevine. BMC Plant Biology 13: 1-15.

Boubakri, H.; Chong, J.; Poutaraud, A.; Schmitt, C.; Bertsch, C.; Mliki, A.; Masson, J.; Soustre-Gacougnolle, I. 2013b. Riboflavin (Vitamin B2) induces defence responses and resistance to Plasmopara viticola in grapevine. European Journal of Plant Pathology 136: 837-855.

Conrath, U. 2009. Priming of induced plant defense responses. Advances in Botanical Research 51: 361-395

Chini, A.; Fonseca, S.; Chico, J.M.; Fernández-Calvo, P.; Solano, R. 2009. The ZIM domain mediates homo-and heteromeric interactions between Arabidopsis JAZ proteins. The Plant Journal 59: 77-87.

Chirkov, S.N. 2002. The antiviral activity of Chitosan (Review). Applied Biochemistry and Microbiology 38: 1-8.

Dempsey, D.M.A.; Klessig, D.F. 2012. SOS - too many signals for systemic acquired resistance? Trends in Plant Science 17: 538545.
Dicke, M.; Baldwin, I.T. 2010. The evolutionary context for herbivore-induced plant volatiles: beyond the 'cry for help'. Trends in Plant Science 15: 167-175.

Dong, H.; Beer, S.V. 2000. Riboflavin induces disease resistance in plants by activating a novel signal transduction pathway. Phytopathology 90: 801-811.

El Modafar, C.; Elgadda, M.; El Boutachfaiti, R.; Abouraicha, E.; Zehhar, N.; Petit, E.; El Alaoui-Talibi, Z.; Courtois, B.; Courtois, J. 2012. Induction of natural defence accompanied by salicylic acid-dependant systemic acquired resistance in tomato seedlings in response to bioelicitors isolated from green algae. Scientia Horticulturae 138: 55-63.

Erb, M.; Veyrat, N.; Robert, C.A.M.; Xu, H.; Frey, M.; Ton, J.; Turlings, T.C.J. 2015. Indole is an essential herbivore-induced volatile priming signal in maize. Nature Communications 6: 6273.

Faize, M.; Faize, L.; Koike, N.; Ishizaka, M.; Ishii, H. 2004. Acibenzolar-S-methyl-induced resistance to Japanese pear scab is associated with potentiation of multiple defense responses. Phytopathology 94: 604-612.

Fernández-Crespo, E.; Camañes, G.; Garcia-Agustin, P. 2012. Ammonium enhances resistance to salinity stress in citrus plants. Journal of Plant Physiology 169: 1183-1191.

Fernández-Crespo, E.; Gómez-Pastor, R.; Scalschi, L.; Llorens, E.; Camañes, G.; García-Agustín, P. 2014. NH4 + induces antioxidant cellular machinery and provides resistance to salt stress in citrus plants. Trees 28: 1693-1704.

Ferri, M.; Tassoni, A.; Franceschetti, M.; Righetti, L.; Naldrett, M.J.; Bagni, N. 2009. Chitosan treatment induces changes of protein expression profile and stilbene distribution in Vitis vinifera cell suspensions. Proteomics 9: 610-624.

Fitza, K.N.E.; Payn, K.G.; Steenkamp, E.T.; Myburg, A.A.; Naidoo, S. 2013. Chitosan application improves resistance to Fusarium circinatum in Pinus patula. South African Journal of Botany 85: 70-78.

Ford, K.A.; Casida, J.E.; Chandran, D.; Gulevich, A.G.; Okrent, R.A.; Durkin, K.A.; Sarpong, R.; Bunnelle, E.M.; Wildermuth, M.C. 2010. Neonicotinoid insecticides induce salicylateassociated plant defense responses. Proceedings of the National Academy of Sciences 107: 17527-17532.

Francis, M.I.; Redondo, A.; Burns, J.K.; Graham, J.H. 2009. Soil application of imidacloprid and related SAR-inducing compounds produces effective and persistent control of citrus canker. European Journal of Plant Pathology 124: 283-292.

Friedrich, L.; Lawton, K.; Ruess, W.; Masner, P.; Specker, N.; Rella, M.G.; Meier, B.; Dincher, S.; Staub, T.; Uknes, S.; Métraux, J.P.; Kessmann, H.; Ryals, J. 1996. A benzothiadiazole derivative induces systemic acquired resistance in tobacco. The Plant Journal 10: 61-70.

Gauthier, A.; Trouvelot, S.; Kelloniemi, J.; Frettinger, P.; Wendehenne, D.; Daire, X.; Joubert, J.M.; Ferrarini, A.; Delledonne, M.; Flors, V.; Poinssot, B. 2014. The sulfated laminarin triggers a stress transcriptome before priming the SA- and ROS-dependent defenses during grapevine's induced resistance against Plasmopara viticola. PLoS ONE 9: e88145.

Glazebrook, J. 2005. Contrasting mechanisms of defense against biotrophic and necrotrophic pathogens. Annual Review of Phytopathology 43: 205-227. 
Goellner, K.; Conrath, U. 2008. Priming: it's all the world to induced disease resistance. European Journal of Plant Pathology 121: 233-242.

Gomi, K.; Yamasaki, Y.; Yamamoto, H.; Akimitsu, K. 2003. Characterization of a hydroperoxide lyase gene and effect of C6-volatiles on expression of genes of the oxylipin metabolism in Citrus. Journal of Plant Physiology 160: 1219-1231.

Goyer, A. 2010. Thiamine in plants: aspects of its metabolism and functions. Phytochemistry 71: 1615-1624.

Gozzo, F.; Faoro, F. 2013. Systemic acquired resistance (50 years after discovery): moving from the lab to the field. Journal of Agricultural and Food Chemistry 61: 12473-12491.

Graham, J.H.; Colburn, G.C.; Chung, K.R.; Cubero, J. 2012. Protection of citrus roots against infection by Phytophthora spp. by hypovirulent $P$. nicotianae is not related to induction of systemic acquired resistance. Plant and Soil 358: 39-49.

Graham, J.H.; Myers, M.E. 2011. Soil application of SAR inducers imidacloprid, thiamethoxam, and Acibenzolar-S-methyl for citrus canker control in young grapefruit trees. Plant Disease 95: 725-728.

Hammerschmidt, R. 2009. Systemic acquired resistance. p. 173222. In: Van Loon, L.C., ed. Advances in botanical research. Academic Press, New York, NY, USA.

Hammerschmidt, R. 2012. Secondary metabolites and defense: the story continues. Physiological and Molecular Plant Pathology 80: 3-4.

Hammond-Kosack, K.; Parker, J. 2003. Deciphering plantpathogen communication: fresh perspectives for molecular resistance breeding. Current Opinion in Biotechnology 14: 177-193.

Harm, A.; Kassemeyer, H.H.; Seibicke, T.; Regner, F. 2011. Evaluation of chemical and natural resistance inducers against downy mildew (Plasmopara viticola) in Grapevine. American Journal of Enology and Viticulture 62: 184-192.

Heil, M.; Ton, J. 2008. Long-distance signalling in plant defence. Trends in Plant Science 13: 264-272.

Hirao, T.; Okazawa, A.; Harada, K.; Kobayashi, A.; Muranaka, T.; Hirata, K. 2012. Green leaf volatiles enhance methyl jasmonate response in Arabidopsis. Journal of Bioscience and Bioengineering 114: 540-545.

Hodges, D.M.; Toivonen, P.M.A. 2008. Quality of fresh-cut fruits and vegetables as affected by exposure to abiotic stress. Postharvest Biology and Technology 48: 155-162.

Jakab, G.; Cottier, V.; Toquin, V.; Rigoli, G.; Zimmerli, L.; Metraux, J.P.; Mauch-Mani, B. 2001. $\beta$-Aminobutyric acid-induced resistance in plants. European Journal of Plant Pathology 107: 29-37.

Jones, J.D.G.; Dangl, J.L. 2006. The plant immune system. Nature 444: 323-329.

Jung, H.W.; Tschaplinski, T.J.; Wang, L.; Glazebrook, J.; Greenberg, J.T. 2009. Priming in systemic plant immunity. Science 324: 89-91.

Kassanis, B.; White, R.F. 1975. Polyacrylic acid-induced resistance to tobacco mosaic virus in tobacco cv. Xanthi. Annals of Applied Biology 79: 215-220.

Li, J.; Trivedi, P.; Wang, N. 2015. Field evaluation of plant defense inducers for the control of citrus Huanglongbing. Phytopathology 106: 37-46
Lorenzo, O.; Piqueras, R.; Sánchez-Serrano, J.J.; Solano, R. 2003. Ethylene response factor 1 integrates signals from ethylene and jasmonate pathways in plant defense. The Plant Cell Online 15: $165-178$.

Louws, F.J.; Wilson, M.; Campbell, H.L.; Cuppels, D.A.; Jones, J.B.; Shoemaker, P.B.; Sahin, F.; Miller, S.A. 2001. Field control of bacterial spot and bacterial speck of tomato using a plant activator. Plant Disease 85: 481-488.

Llorens, E.; Fernandez-Crespo, E.; Vicedo, B.; Lapena, L.; GarciaAgustin, P. 2013. Enhancement of the citrus immune system provides effective resistance against Alternaria brown spot disease. Journal of Plant Physiology 170: 146-154.

Llorens, E.; Vicedo, B.; López, M.M.; Lapeña, L.; Graham, J.H.; García-Agustín, P. 2015. Induced resistance in sweet orange against Xanthomonas citri subsp. citri by hexanoic acid. Crop Protection 74: 77-84.

Ma, Z.; Yang, L.; Yan, H.; Kennedy, J.F.; Meng, X. 2013. Chitosan and oligochitosan enhance the resistance of peach fruit to brown rot. Carbohydrate Polymers 94: 272-277.

Macarisin, D.; Wisniewski, M.E.; Bassett, C.; Thannhauser, T.W. 2009. Proteomic analysis of beta-aminobutyric acid priming and abscisic acid - induction of drought resistance in crabapple (Malus pumila): effect on general metabolism, the phenylpropanoid pathway and cell wall enzymes. Plant Cell and Environment 32: 1612-1631.

Malamy, J.; Sánchez-Casas, P.; Hennig, J.; Guo, A.; Klessig, D.F. 1996. Dissection of the salicylic acid signaling pathway in tobacco. Molecular Plant-Microbe Interactions 9: 474-482.

Maxson-Stein, K.; He, S.Y.; Hammerschmidt, R.; Jones, A.L. 2002. Effect of treating apple trees with Acibenzolar-S-methyl on fire blight and expression of pathogenesis-related protein genes. Plant Disease 86: 785-790.

Nair, A.; Kolet, S.P.; Thulasiram, H.V.; Bhargava, S. 2015. Systemic jasmonic acid modulation in mycorrhizal tomato plants and its role in induced resistance against Alternaria alternata. Plant Biology 17: 625-631.

Obanor, F.; Walter, M.; Jones, E.E.; Jaspers, M. 2013. Efficacy of systemic acquired resistance inducers in olive leaf spot management. Australasian Plant Pathology. 42: 163-168.

Oostendorp, M.; Kunz, W.; Dietrich, B.; Staub, T. 2001. Induced disease resistance in plants by chemicals. European Journal of Plant Pathology 107: 19-28.

Osbourn, A.E. 1996. Preformed antimicrobial compounds and plant defense against fungal attack. The Plant Cell Online 8: 1821-1831.

Pastor, V.; Luna, E.; Mauch-Mani, B.; Ton, J.; Flors, V. 2013. Primed plants do not forget. Environmental and Experimental Botany 94: 46-56.

Pastor, V.; Pena, A.; Gamir, J.; Flors, V.; Mauch-Mani, B. 2014. Preparing to fight back: generation and storage of priming compounds. Frontiers in Plant Science 5: 295.

Pieterse, C.M.J.; Van Loon, L.C. 2004. NPR1: The spider in the web of induced resistance signaling pathways. Current Opinion in Plant Biology 7: 456-464.

Pieterse, C.M.J.; Van Loon, L.C. 2007. Signalling cascades involved in induced resistance. p. 65-88. In: Walters, D.; Newton, A.C.; Lyon G., eds. Induced resistance for plant defence. Blackwell, London, UK. 
Pieterse, C.M.J.; Van Pelt, J.A.; Ton, J.; Parchmann, S.; Mueller, M.J.; Buchala, A.J.; Métraux, J.P.; Van Loon, L.C. 2000. Rhizobacteria-mediated induced systemic resistance (ISR) in Arabidopsis requires sensitivity to jasmonate and ethylene but is not accompanied by an increase in their production. Physiological and Molecular Plant Pathology 57: 123-134.

Pieterse, C.M.J.; Zamioudis, C.; Berendsen, R.L.; Weller, D.M.; Van Wees, S.C.M.; Bakker, P.A.H.M. 2014. Induced systemic resistance by beneficial microbes. Annual Review of Phytopathology 52: 347-375.

Pozo, M.J.; Van Der Ent, S.; Van Loon, L.C.; Pieterse, C.M.J. 2008. Transcription factor MYC2 is involved in priming for enhanced defense during rhizobacteria-induced systemic resistance in Arabidopsis thaliana. New Phytologist 180: 511-523.

Prats, E.; Rubiales, D.; Jorrín, J. 2002. Acibenzolar-S-methylinduced resistance to sunflower rust (Puccinia helianthi) is associated with an enhancement of coumarins on foliar surface. Physiological and Molecular Plant Pathology 60: 155-162.

Pré, M.; Atallah, M.; Champion, A.; De Vos, M.; Pieterse, C.M.J.; Memelink, J. 2008. The AP2/ERF domain transcription factor ORA59 integrates jasmonic acid and ethylene signals in plant defense. Plant Physiology 147: 1347-1357.

Pritchard, L.; Birch, P.R.J. 2014. The zigzag model of plantmicrobe interactions: is it time to move on? Molecular Plant Pathology 15: 865-870.

Reglinski, T.; Taylor, J.; Dick, M. 2004. Chitosan induces resistance to pitch canker in Pinus radiata. New Zealand Journal of Forestry Science 34: 49-58.

Reuveni, M.; Zahavi, T.; Cohen, Y. 2001. Controlling downy mildew (Plasmopara viticola) in field-grown grapevine with $\beta$-aminobutyric acid (BABA). Phytoparasitica 29: 125-133.

Romero, A.M.; Kousik, C.S.; Ritchie, D.F. 2001. Resistance to bacterial spot in bell pepper induced by Acibenzolar-S-methyl. Plant Disease 85: 189-194.

Scalschi, L.; Camañes, G.; Llorens, E.; Fernández-Crespo, E.; López, M.M.; García-Agustín, P.; Vicedo, B. 2014. Resistance inducers modulate Pseudomonas syringae pv. Tomato Strain DC3000 response in tomato plants. PLoS ONE 9: e106429.

Shah, J.; Zeier, J. 2013. Long-distance communication and signal amplification in systemic acquired resistance. Frontiers in Plant Science 4: 30.

Soufleros, E.H.; Mygdalia, S.A.; Natskoulis, P. 2005. Production process and characterization of the traditional Greek fruit distillate "Koumaro" by aromatic and mineral composition. Journal of Food Composition and Analysis 18: 699-716.
Tiwari, S.; Meyer, W.L.; Stelinski, L.L. 2013. Induced resistance against the Asian citrus psyllid, Diaphorina citri, by $\beta$-aminobutyric acid in citrus. Bulletin of Entomological Research 103: 592-600.

Ton, J.; Jakab, G.; Toquin, V.; Flors, V.; Iavicoli, A.; Maeder, M.N.; Métraux, J.P.; Mauch-Mani, B. 2005. Dissecting the $\beta$-aminobutyric acid-induced priming phenomenon in Arabidopsis. Plant Cell 17: 987-999.

Tripathi, D.; Jiang, Y.L.; Kumar, D. 2010. SABP2, a methyl salicylate esterase is required for the systemic acquired resistance induced by Acibenzolar-S-methyl in plants. FEBS letters 584: 3458-3463.

Trouvelot, S.; Varnier, A.L.; Allegre, M.; Mercier, L.; Baillieul, F.; Arnould, C.; Gianinazzi-Pearson, V.; Klarzynski, O.; Joubert, J.M.; Pugin, A.; Daire, X. 2008. A $\beta-1,3$ glucan sulfate induces resistance in grapevine against Plasmopara viticola through priming of defense responses, including HR-like cell death. Molecular Plant-Microbe Interactions 21: 232-243.

Vallad, G.E.; Goodman, R.M. 2004. Systemic acquired resistance and induced systemic resistance in conventional agriculture. Crop Science 44: 1920-1934.

Van Hulten, M.; Pelser, M.; Van Loon, L.C.; Pieterse, C.M.J.; Ton, J. 2006. Costs and benefits of priming for defense in Arabidopsis. Proceedings of the National Academy of Sciences 103: 5602-5607.

Van Loon, L.C.; Bakker, P.A.H.M.; Pieterse, C.M.J. 1998. Systemic resistance induced by rhizosphere bacteria. Annual Review of Phytopathology 36: 453-483.

Van Loon, L.C.; Rep, M.; Pieterse, C.M.J. 2006. Significance of inducible defense-related proteins in infected plants. Annual Review of Phytopathology 44: 135-162.

Vernooij, B.; Friedrich, L.; Morse, A.; Reist, R.; Kolditz-Jawhar, R.; Ward, E.; Uknes, S.; Kessmann, H.; Ryals, J. 1994. Salicylic acid is not the translocated signal responsible for inducing systemic acquired resistance but is required in signal transduction. The Plant Cell Online 6: 959-965.

Vicedo, B.; Flors, V.; Leyva, M.D.; Finiti, I.; Kravchuk, Z.; Real, M.D.; Garcia-Agustin, P.; Gonzalez-Bosch, C. 2009. Hexanoic acid-induced resistance against Botrytis cinerea in tomato plants. Molecular Plant-Microbe Interactions 22: 1455-1465.

Walters, D.; Heil, M. 2007. Costs and trade-offs associated with induced resistance. Physiological and Molecular Plant Pathology 71: 3-17. 